\title{
Correction to: Pharmaceuticals in groundwaters: a case study of the psychiatric hospital at Horní Beřkovice, Czech Republic
}

\author{
D. Rozman ${ }^{1,2} \cdot$ Z. Hrkal $^{1,2} \cdot$ P. Eckhardt ${ }^{1} \cdot$ E. Novotná ${ }^{1} \cdot$ Z. Boukalová $^{3,4}$
}

Published online: 5 August 2019

○) Springer-Verlag GmbH Germany, part of Springer Nature 2019

\section{Correction to: Environ Earth Sci (2015) 73:3775-3784 https://doi.org/10.1007/s12665-014-3663-1}

The authors would like to correct errors in the original publication as detailed below.

The correct version of the authors affiliations is given here:

D. Rozman $(\square)$

T.G. Masaryk Water Research Institute, Podbabská 30, 160

00 Praha 6, Czech Republic

Institute of Hydrogeology, Engineering Geology and Applied Geophysics, Faculty of Sciences, Charles University, Albertov 6, 12843 Praha 2, Czech Republic

e-mail: rozman@vuv.cz

\section{Z. Hrkal}

T.G. Masaryk Water Research Institute, Podbabská 30, 160 00 Praha 6, Czech Republic

Institute of Hydrogeology, Engineering Geology and Applied Geophysics, Faculty of Sciences, Charles University, Albertov 6, 12843 Praha 2, Czech Republic

The original article can be found online at https://doi.org/10.1007/ s12665-014-3663-1.

D. Rozman

rozman@vuv.cz

1 T.G. Masaryk Water Research Institute, Podbabská 30, 16000 Praha 6, Czech Republic

2 Institute of Hydrogeology, Engineering Geology and Applied Geophysics, Faculty of Sciences, Charles University, Albertov 6, 12843 Praha 2, Czech Republic

3 Vodní Zdroje a.s, Jindřicha Plachty 16, 15000 Praha 5, Czech Republic

4 Department of Physical Geography and Geoecology, Faculty of Sciences, Charles University, Albertov 6, 12843 Praha 2, Czech Republic
P. Eckhardt

T.G. Masaryk Water Research Institute, Podbabská 30, 160 00 Praha 6, Czech Republic

E. Novotná

T.G. Masaryk Water Research Institute, Podbabská 30, 160 00 Praha 6, Czech Republic

Z. Boukalová

Vodní Zdroje a.s., Jindřicha Plachty 16, 15000 Praha 5, Czech Republic

Department of Physical Geography and Geoecology, Faculty of Sciences, Charles University, Albertov 6, 12843 Praha 2, Czech Republic

Publisher's Note Springer Nature remains neutral with regard to jurisdictional claims in published maps and institutional affiliations. 